\title{
Walory historyczne i artystyczne kościoła pw. Świętych Wojciecha i Stanisława w Wilamowie
}

STRESZCZENIE | Neogotycki kościół pw. św. Wojciecha Biskupa i Męczennika i św. Stanisława Biskupa i Męczennika w Wilamowie to przykład zabytkowej sztuki sakralnej na terenie gminy Uniejów. Mimo że ma wartość zabytkową oraz położony jest w pobliżu głównych tras komunikacyjnych, pozostaje obiektem mało znanym. W obiegowej opinii funkcjonuje raczej jako niewielki kościół wiejski niż godny uwagi i wart odwiedzenia obiekt sakralny.

W artykule przedstawiono na podstawie analizy specjalistycznej literatury, źródeł pisanych oraz przekazów ustnych historię kościoła oraz parafii, których okoliczności powstania osnute są lokalnymi legendami. Omówiono ponadto wystrój i otoczenie zabytku, skupiając się przede wszystkim na walorach historycznych i artystycznych obiektu, których analiza wykazała potencjał turystyczny miejsca i możliwości wykorzystania go jako celu w kontekście turystyki dziedzictwa kulturowego.

SŁOWA KLUCZOWE | Wilamów, kościół, sztuka, wartość artystyczna

\section{Wstęp}

Kościół pw. św. Wojciecha Biskupa i Męczennika i św. Stanisława Biskupa i Męczennika w Wilamowie (gmina Uniejów, powiat poddębicki, woj. łódzkie) został wzniesiony w 1894 r. Utrzymany w stylu romantycznym, zarówno w wystroju, jak i otoczeniu, pod względem estetycznym jest obiektem pełnym uroku, wpisanym nieodłącznie w krajobraz wsi Wilamów.

Wewnątrz przeszło I20-letnich murów znajdują się m.in.: dwa XIX-wieczne ołtarze boczne z wizerunkiem Matki Boskiej Pocieszenia z rzemiennym

\footnotetext{
Agnieszka Owczarek, mgr, absolwentka Uniwersytetu im. A. Mickiewicza w Poznaniu, Instytut Filologii Romańskiej; Urząd Miasta w Uniejowie, Dział Promocji, ul. bł. Bogumiła I3, 99-2Io Uniejów; e-mail: agnieszka.owczarek@uniejow.pl
} 
paskiem oraz z czarnym krucyfiksem. Uroczystą atmosferę podczas celebracji liturgii nadają oryginalne organy warszawskiego organomistrza Ignacego Karczewskiego. We wnętrzu znajdują się także starsze zabytki, jak choćby XVII-wieczny obraz Matki Boskiej Pocieszenia słynący łaskami czy XIV-wieczna chrzcielnica gotlandzkiej proweniencji.

Mimo niewątpliwych walorów historycznych i artystycznych wilamowski kościół wciąż jest obiektem mało znanym. Przyczyn można upatrywać m.in. w braku przeprowadzenia gruntownych badań obiektu przez historyków sztuki i konserwatorów zabytków ${ }^{1}$. Nie ukazała się dotychczas żadna publikacja krajoznawcza (np. przewodnik) z kwerendą dotyczącą głównych zabytków, która wyjaśniłaby, na czym polega wyjątkowość kościoła w Wilamowie.

Niniejszy tekst jest więc próbą scharakteryzowania świątyni pod kątem jej głównych walorów historycznych i artystycznych przy założeniu, że wilamowski kościół może być celem wypraw turystycznych, zwłaszcza tych dotyczących dziedzictwa kulturowego.

Artykuł składa się z trzech zasadniczych części. W pierwszej zostanie omówiona historia kościoła i parafii, która sięga swymi korzeniami XV w.

W drugiej części poddano analizie czynniki wpływające na atrakcyjność obiektu, takie jak: architektura, wyposażenie i wystrój wnętrza oraz wybrane wątki ikonograficzne w zakresie polichromii i ołtarzy.

Ostatnią część artykułu poświęcono omówieniu mocnych i słabych stron z perspektywy turystyki dziedzictwa kulturowego.

W pracy uwzględniono dane archiwalne, zebraną dotychczas dokumentację konserwatorską, specjalistyczną literaturę przedmiotu, przekazy ustne i konsultacje z rzeczoznawcami.

\section{Historia parafii i kościoła}

Najstarsza informacja piśmienna o wsi pochodzi z dokumentu wydanego przez księcia Władysława Odonica w I232 r., który wspomina o przynależności Wilamowa do kasztelani lądzkiej². Była to wieś szlachecka, gniazdo rodowe rodziny Wilamowskich herbu Szassor, do której należeli m.in. Jakub

\footnotetext{
I Dotychczas przebadano jedynie ołtarz znajdujący się w prezbiterium (w 1996 r.) oraz ołtarze boczne (w 2014 i 2018 r.) w związku z pracami konserwatorskimi tychże elementów.

2 P. Żmudzki, Studium podzielonego królestwa. Książe Leszek Czarny, Warszawa 200o, s. 67.
} 
Wilamowski, poseł Zygmunta I do sułtana tureckiego Sulejmana w I53 I r., i Jan Wilamowski, biskup kamieniecki (zm. w I540 r.) ${ }^{3}$.

Parafia powstała w II poł. XV w. Akta konsystorskie wzmiankują o istnieniu drewnianego kościoła parafialnego ${ }^{4}$ pw. Świętych Wojciecha i Stanisława Biskupów Męczenników, którego plebanem był ks. Marcin z Iwanowa. Powstał on najprawdopodobniej z fundacji rodu Wilamowskich, będących dziedzicami dóbr ${ }^{5}$, gdyż mieszkańców maleńkiej wioski nie byłoby stać na wybudowanie świątyni. W dniu I4 marca I575 r. Wspomniano, że do kościoła należały dziesięciny z Czepowa, a 22 stycznia I6or r. skopiowany został dokument erekcji kościoła w Wilamowie. Do ówczesnej parafii należały wsie: Wilamów, Radyczyny, Łęg, Sarbice, Podłużyce, Kozubów, Lekaszyn, Brzozówka i Cichmiana ${ }^{6}$.

Losy drewnianych kościołów często kończyły się pożarami. Nie inaczej było w przypadku świątyni w Wilamowie, którą przynajmniej dwukrotnie trawił ogień.

Po I5I8 r. wystawiono nowy kościół pw. Świętych Mateusza, Wojciecha i Stanisława7, który według tradycji ufundowany był przez królową Bonę ${ }^{8}$.

W I65 I r. kościół, jak również cała parafia zostały objęte interdyktem z powodu zabójstwa, którego miejscowi kmiecie dopuścili się na plebanie. Za ten czyn na parafię nałożono klątwę i zlikwidowano ją na pewien okres, przyłączając wiernych do parafii w Uniejowie.

Kolejna udokumentowana wzmianka o świątyni miała miejsce w I765 r. Odnotowano wówczas protest w sprawie naruszenia prawa kościoła

3 T. Grabarczyk, A. Kowalska-Pietrzak, J. Szymczak, Karty z przeszłości odległej, nieznanej i bliskiej gminy Uniejów, J. Szymczak (red.), Łódź-Uniejów 2008, s. I57.

4 Według przekazywanej przez pokolenia legendy drewno przeznaczone na budowę składowano w pobliskiej Cichmianie, gdyż właśnie tam miał stanąć kościół. $\mathrm{Na}$ skutek powodzi drewniane belki odpłynęły wraz z cofającą się falą i woda pozostawiła je w Wilamowie. Odebrano to jako znak, że właśnie w tym miejscu powinna stanąć świątynia. Zbudowano wówczas niewielki kościółek Świętych Wojciecha i Stanisława.

5 J. Łaski, Liber Beneficiorum Archidioecesis Gnesnensis, t. I, Gniezno I88o, s. 363.

6 T. Grabarczyk, A. Kowalska-Pietrzak, J. Szymczak, Uniejowskie strony..., s. 157.

7 S. Librowski, Repetytorium Akt Wizytacji Kanonicznych dawnej archidiecezji gnieźnieńskiej, t. I, z. I, s. 97.

8 W parafialnej broszurze wydanej z okazji stulecia konsekracji świątyni podano informację, że fundatorką drugiego drewnianego kościoła miała być królowa Bona Sforza. Informacja ta powielana jest w dostępnych przewodnikach i popularnych opracowaniach, jednak należy ją zweryfikować. 
w Wilamowie i należącej do niego ziemi. Z 1778 r. pochodzi informacja o patronacie kościoła w Wilamowie?.

Po pożarze w I807 r. odbudowę ufundował sędzia sieradzki Józef Załustowski, a po jego śmierci fundację kontynuował jego syn Leon - dziedzic sąsiedniej wsi Skotniki. Obecna świątynia została wzniesiona w I894 r. przez biskupstwo włocławskie przy dużym wsparciu i pomocy dziedzica Stanisława Pieczyńskiego z majątku Czepów. Miało to miejsce w czasach, gdy miejscowym proboszczem był ks. Paweł Romanowski, którego grób znajduje się na lokalnym cmentarzu parafialnym. Świątynia została konsekrowana 24 kwietnia 1909 r. przez biskupa Stanisława Zdzitowieckiego ${ }^{10}$.

Kościelne dzieje Wilamowa w przeważającej części związane są z archidiecezją gnieźnieńską, do której parafia należała od początku swego istnienia do I8I8 r. Po tej dacie w Królestwie Polskim wprowadzono podział na osiem diecezji odpowiadających terytorialnie poszczególnym województwom, w wyniku czego omawiana parafia została włączona w latach I8I8-I925 do diecezji kujawsko-kaliskiej ${ }^{\text {II }}$.

Po odzyskaniu przez Polskę niepodległości nastąpiła kolejna reorganizacja administracji kościelnej na podstawie konkordatu podpisanego z Watykanem w dniu ıo lutego I925 r. Przynależność parafii nie uległa wprawdzie zmianie, zmieniła się natomiast nazwa diecezji, powrócono bowiem do dawnego nazewnictwa - diecezji włocławskiej.

Wilamowska parafia od początku swego istnienia związana była z archidiakonatem uniejowskim, który powstał w już w XII w. i obejmował początkowo obszar dekanatów: uniejowskiego, warckiego, szadkowskiego i brzeźnickiego (ten ostatni przeszedł później do archidiakonatu łowickiego) ${ }^{12}$. Podział na archidiakonaty zanikł w II poł. XVIII w., a wraz z nim przestał istnieć archidiakonat uniejowski. Parafia należała wówczas do dekanatu uniejowskiego, a po jego rozwiązaniu w I867 r. została włączona do dekanatu tureckiego. Ponowne powstanie dekanatu uniejowskiego w I9I6 r. skutkowało powtórnym włączeniem do niego parafii Wilamów ${ }^{13}$.

\footnotetext{
9 T. Grabarczyk, A. Kowalska-Pietrzak, J. Szymczak, Uniejowskie strony..., s. 157.

Io G.B. Bednarek, Wilamów. Parafia pw. patronów Polski św. Wojciecha i św. Stanistawa. Historia parafii, [online] „Katolickie Media” 20I7, katolickie.media.pl [dostęp: 21.05.2021]. II W. Kujawski, Rola Instytucji Kościelnych w życiu miasta, [w:] J. Szymczak (red.), Uniejów, dzieje miasta, Łódź-Uniejów I995, s. 373.

I2 Tamże, s. 376.

13 Tamże, s. 404.
} 
Do obecnej parafii Wilamów należą Brzozówka, Góry, Lekaszyn i Wilamów z gm. Uniejów oraz Augustynów, Cichmiana i Krzykosy z gm. Dąbie; ogółem 980 wiernych. Od 2006 r. proboszczem jest ks. Bogusław Karasiński, a przed nim w latach 1980-2006 parafią kierował ks. Jan Sroka.

\section{Architektura}

Kościół usytułowany jest w centrum Wilamowa. Posesja została otoczona ogrodzeniem ${ }^{\mathrm{I}}$. Na przestrzeni lat budynek nie przeszedł wielu gruntownych remontów, można więc uznać, że zachował swój pierwotny wystrój.

Pod względem stylu architektonicznego świątynia wpisuje się jeszcze w nurt romantyczny, chociaż umownie przyjmuje się rok I863 za datę końca epoki romantyzmu w Polsce ${ }^{\mathrm{rs}}$. Architektura romantyczna wyrosła na gruncie zafascynowania średniowieczem i naturą, czego wyrazem było sięganie przede wszystkim do wzorców gotyckich, które stanowiły inspirację nie tylko estetyczną, ale też ideologiczną. Neogotyk był stylem często stosowanym w okresie fascynacji historią, co przekładało się również na architekturę. Strzeliste wieże wyrażają zainteresowanie człowieka duchowością i sferą sacrum.

Do neogotyku odwołuje się pod względem stylu także kościół wilamowski. Obiekt wzniesiony na planie krzyża łacińskiego jest trójnawowy, halowy z dwuprzęsłowym korpusem i jednonawowym transeptem (ryc. I). Do wielobocznie zakończonego prezbiterium dobudowano zakrystię i kaplicę pogrzebową. Nawa główna kościoła jest doświetlona za pomocą wysokich, zakończonych ostrołukiem okien umieszczonych w ścianach naw bocznych. Harmonijną bryłę, pokrytą dwuspadowym dachem, wzbogacono niewielką wieżyczką na osi fasady, która pełni funkcję dzwonnicy z trzema dzwonami o znamiennych imionach: Wojciech, Stanisław i Karol.

I4 Zabytkowe kute przęsła, które zdobiły ogrodzenie wokół kościoła parafialnego, zostały zrabowane przez hitlerowców i przetopione na broń. Prawdopodobnie, ze względu na szacunek do zmarłych, okupanci nie rozgrabili jedynie ogrodzenia miejscowej nekropolii wykonanej z tego samego materiału, zob. M. Bartosiak, W setna pamiątkę urodzin Ojca Świętego, Jana Pawła II..., [online] https://uniejow. pl/aktualnosci/_trashed-5.html [dostęp: 26.05.2021].

I5 Romantyzm - charakterystyka epoki (ramy czasowe, nazwa epoki, filozofia), [online] https://eszkola.pl/jezyk-polski/romantyzm--978.html [dostęp: 26.05.202I]. 


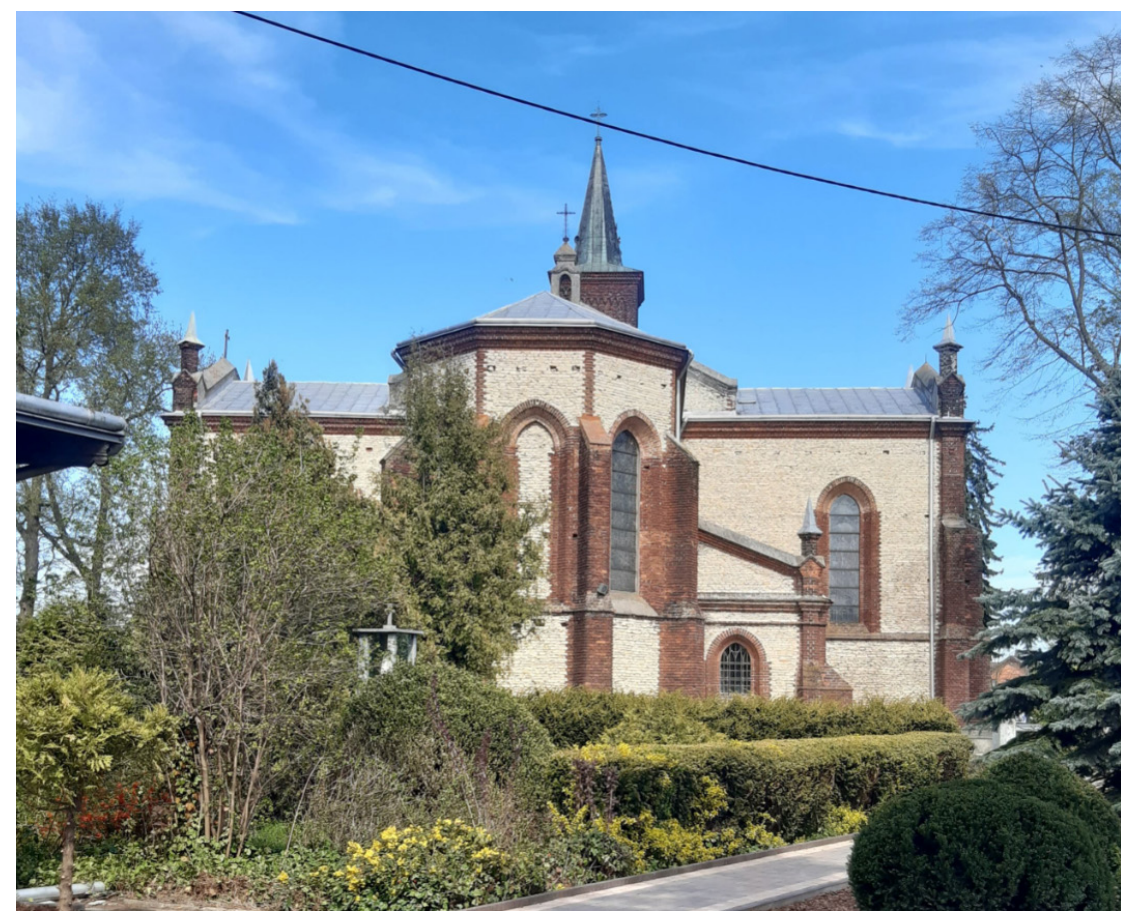

Ryc. I. Widok na kościół w Wilamowie od strony plebanii Źródło: galeria zdjęć Urzędu Miasta w Uniejowie

Kościół charakteryzuje typowa dla stylu smukłość i strzelistość. Zwarte i dające wrażenie jednoprzestrzenności wnętrze koresponduje z bryłą zewnętrzną. Mury zewnętrzne wykonane z lokalnego surowca - tzw. opoki rożniatowskiej - są nieotynkowane. Do świątyni prowadzą drzwi główne $\mathrm{i}$ jedne boczne.

\section{Ołtarze}

Wewnątrz świątyni znajduje się sześć ołtarzy: dawny ołtarz główny marmurowy, ołtarz soborowy z granitu skandynawskiego i cztery ołtarze drewniane o bocznym usytuowaniu.

W prezbiterium pomieszczony jest główny ołtarz z szarego marmuru w stylu gotyckim. Ufundował go ks. Walenty Mruk, pochodzący z parafii Wilamów. Na ołtarzu znajduje się inskrypcja w języku łacińskim: „Fundator Valentinus Mruk Sacerdos, A.D. I896 in hac ecclesia babtisatus”. Wedle przekazu obecnego proboszcza ołtarz ten został wyróżniony w I964 r. pismem 
ks. biskupa Antoniego Pawłowskiego do godności ołtarza (altare maius) odpowiednimi przywilejami ${ }^{16}$.

W ołtarzu znajduje się zabytkowy, malowany na płótnie obraz Matki Boskiej Pocieszenia z Dzieciątkiem, nieznanego autorstwa, datowany na II poł. XVIII w. Słynie on w okolicy z licznych łask i próśb modlitewnych. Jest to prostokątny obraz olejny na płótnie, przedstawiający wizerunek Madonny z Dzieciątkiem Jezus trzymanym na lewej ręce. Madonna ujęta jest frontalnie z twarzą zwróconą en face i wzrokiem skierowanym na patrzącego (ryc. 2). Ubrana jest w czerwoną, karminową suknię z długimi rękawami, przepasaną zieloną szarfą w talii, i w ciemnoniebieski płaszcz ze złotymi lamówkami. Maryja i Jezus mają na obrazie chłodną karnację, utrzymaną w duchu epoki ${ }^{17}$, natomiast ich twarze są pełne ekspresji.
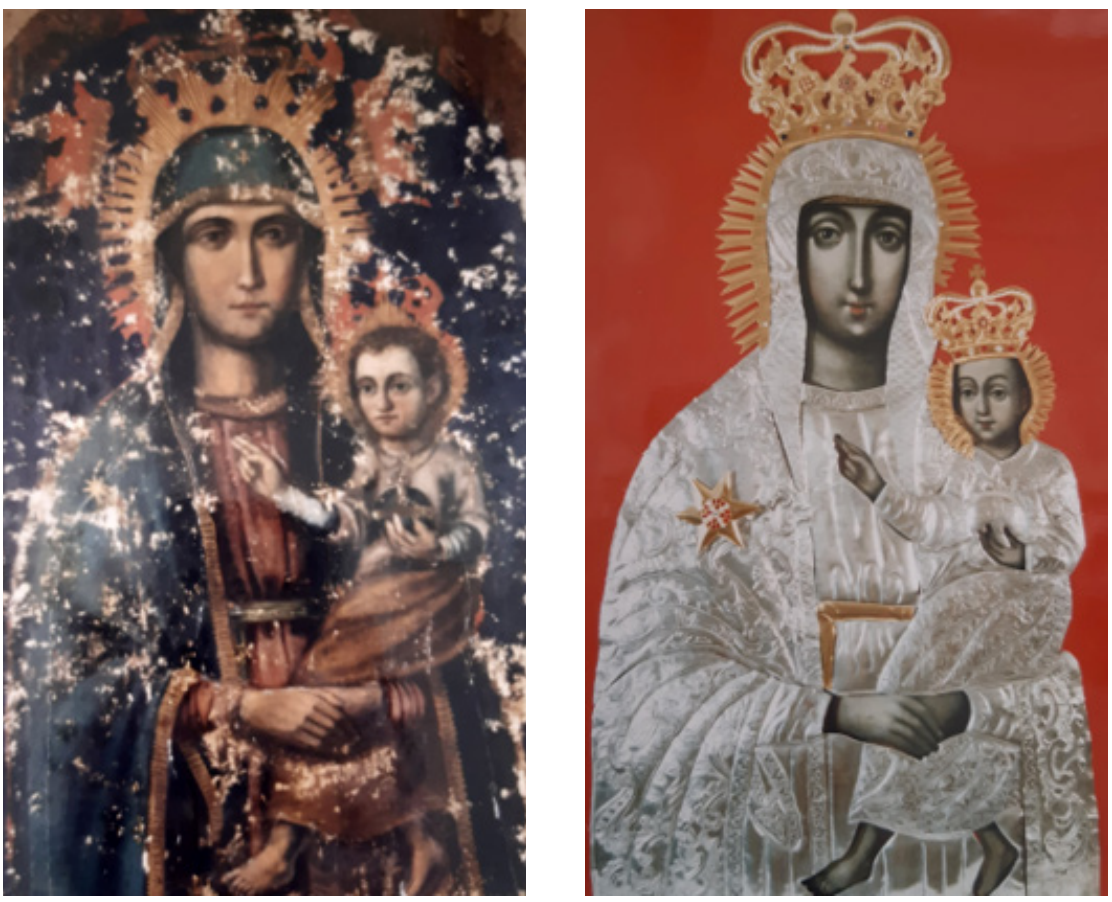

Ryc. 2. Obraz Matki Boskiej Pocieszenia przed i po konserwacji.

Źródło: B. Warszycka, Dokumentacja konserwatorkka obrazu ołtarzowego M.B. z Dzieciątkiem, Wilamów 1995

I6 Akta parafialne dotyczące ołtarza, 1964, pismo I4047.

I7 B. Warszycka, Dokumentacja konserwatorska obrazu ottarzowego M.B. z Dzieciątkiem, Wilamów 1995, s. I. 
Jezus przyodziany jest w jasnoróżową szatę, prawą ręką błogosławi patrzącemu, a w lewej trzyma błękitną kulę ziemską ze złotym krzyżykiem. Nad Madonną znajdują się anioły w geście modlitewnym ${ }^{18}$.

Gruntowne badania przeprowadzone przy okazji prac konserwatorskich w 1996 r. wykazały, że obraz był dwukrotnie przemalowywany w partiach tła w XVIII w. i jednokrotnie w partiach karnacji na początku XIX w. W I774 r. obraz przyozdobiono w sukienkę srebrną pozłacaną, którą ufundowali parafianie za probostwa ks. Jana Zieli. Na sukience znajduje się informacja, że była ona darem na stulecie obrazu, dlatego przyjmuje się, że obraz powstał w I674 r.

W latach 1995-1996 obraz odnowiono. Renowacji poddano także metalową sukienkę z koronami oraz dorobiono snycerską, złoconą, bogatą ramę ze zwieńczeniem nawiązującym do stylu epoki. Obraz był bardzo zniszczony, najmniej uszkodzeń odnotowano na twarzy Madonny. Prace konserwatorskie wykonała konserwator dzieł sztuki Barbara Warszycka z Torunia' ${ }^{19}$.

W ołtarzu nad obrazem Matki Boskiej Pocieszenia znajduje się płaskorzeźba przedstawiająca patrona parafii - św. Walentego - kapłana i męczennika oraz imiennika fundatora.

Obok ołtarza wiszą dwie tablice z wotami. Świadczą one niezbicie o tym, że Matka Boża Pocieszenia odbierała należną i godną cześć, cieszyła się czcią i miłością wiernych, a Jej kult był żywy i owocny ${ }^{20}$.

Po lewej i prawej stronie obrazu znajdują się figury patronów świątyni i Polski - św. Wojciecha i św. Stanisława Szczepanowskiego.

W centrum nastawy ołtarzowej na mensie stoi tabernakulum marmurowe, którego front ozdobiony jest pozłacaną blachą i drzwiczkami wygrawerowanymi postaciami aniołów.

\section{Ołtarz boczny z wizerunkiem}

\section{Matki Boskiej Pocieszycielki i Chrystusa Króla}

W kaplicy południowej znajduje się drewniany ołtarz snycerski, datowany na przełom XIX i XX w. W środkowej niszy umieszczono figurę Chrystusa Króla, która zasłaniana jest obrazem na zasuwie z przedstawieniem Matki Boskiej Pocieszenia z paskiem rzemiennym (ryc. 3). W bocznych niszach

\section{I8 Tamże.}

I9 Tamże, s. 2-3.

$20 \mathrm{~W}$ kaplicy bocznej znajdują się kolejne tablice z wotami. Nie zachowały się jednak księgi dokumentujące doświadczone cuda i łaski. 
umieszczono drewniane rzeźby przedstawiające świętych - św. Antoniego i św. Józefa. Obiekt ma charakter jednokondygnacyjny, trójosiowy i składa się z mensy, predelli, nastawy i zwieńczenia. Gładka, skrzyniowa mensa zdobiona jest złoconymi, profilowanymi ramami. Kolorystykę ołtarza utrzymano w jednolitym, ciemnym odcieniu brązu, natomiast boczne nisze w kolorze ultramaryny ${ }^{21}$.

Obraz Matki Boskiej Pocieszenia jest figuratywnym przedstawieniem Madonny z Dzieciątkiem. W lewej dłoni Matka Boska trzyma skórzany pasek ze sprzączką, unosi się wśród chmur, stopę opiera na księżycu w kształcie sierpa, a nad jej głową znajduje się aureola złożona $\mathrm{z}$ dwunastu gwiazd.

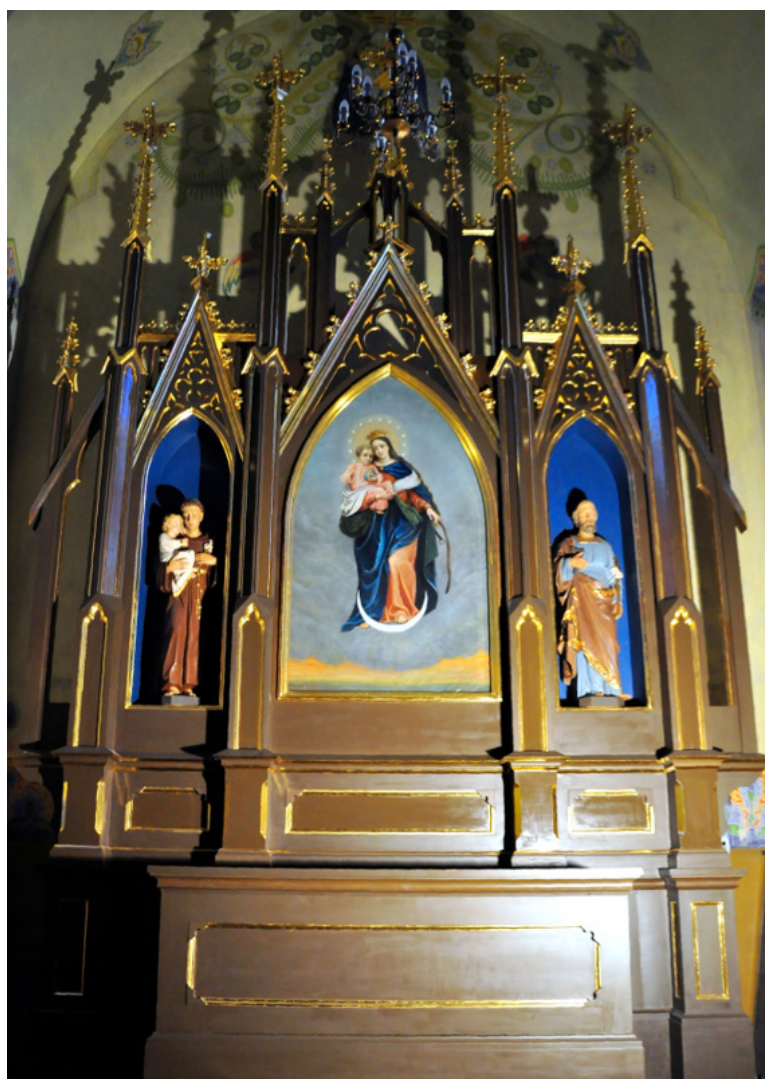

Ryc. 3. Ołtarz boczny z obrazem Matki Boskiej Pocieszenia z rzemiennym paskiem Źródło: galeria zdjęć Urzędu Miasta w Uniejowie

2I E. Kruk, B. Terzyjska, Dokumentacja budowy technicznej oraz prac konserwatorskich ołtarza bocznego z kościoła pw. św. Wojciecha i św. Stanistawa B.M. w Wilamowie, Łódź 20I4, s. 8. 
Madonna ubrana jest w czerwoną suknię i granatowy płaszcz z zielonym podbiciem, natomiast Chrystusa przyodziano w różową tunikę, unosi on prawą dłoń w geście błogosławieństwa, w lewej natomiast dzierży błękitną kulę ze złotym krzyżem. Tło dla kompozycji stanowią kłębiące się chmury.

O ile przedstawienie Madonny z Dzieciątkiem jest popularnym motywem w sztuce, to ukazanie Matki Boskiej trzymającej pasek przypominający skórzany pasek od spodni wydaje się dość osobliwym i intrygującym zabiegiem malarskim. Ten typ przedstawienia ikonograficznego Matki Boskiej Pocieszenia z rzemiennym paskiem wywodzi się z przedstawień związanych z bractwem Augustianów, zgromadzenia zakonnego żyjącego według reguły św. Augustyna z Hippony. Sam zakon zaliczany jest do zakonów żebraczych, a obowiązujący ubiór zakonników to czarny habit z kapturem i skórzanym pasem.

W zakonie od wieków istnieje nabożeństwo i kult Najświętszej Maryi Panny jako Matki Pocieszenia, choć nie jest dokładnie znana jego geneza. Legenda głosi, że Matka Boska objawiała się św. Monice - matce św. Augustyna. Po śmierci męża Patrycjusza święta pragnęła jak najdoskonalej naśladować Maryję, toteż prosiła ją, by objawiła się jej w stroju, który nosiła po śmierci Jezusa, by mogła ją i w tym naśladować. Maryja ukazała się w czarnym, długim okryciu, z czarnym skórzanym paskiem na biodrach. Obiecała szczególną opiekę i pociechę Monice oraz tym wszystkim, którzy ku jej czci noszą skórzany pas.

Święta Monika nosiła odtąd czarne długie okrycie przepasane paskiem, strój ten znalazł swoją kontynuację w habitach założonego przez św. Augustyna zakonu eremitów augustiańskich. Członkowie bractwa naśladują swoją patronkę Monikę nie tylko nosząc swój skórzany pasek, ale oddając się tak jak ona cierpliwej i wytrwałej modlitwie, zachowując silną wiarę i niewzruszoną wierność Bogu²2.

\section{Ołtarz boczny Chrystusa Ukrzyżowanego}

W kaplicy północnej znajduje się kolejny ołtarz wykonany w całości z drewna, zbudowany pod koniec XIX w., o czym świadczy widniejąca na nim inskrypcja o treści „Budował Iwaszkiewicz I897”. To ołtarz przyścienny, wpasowany wysokością i szerokością w nawę boczną kościoła. Pod względem architektonicznym jest symetryczny pod kątem osi pionowej oraz

22 Tamże, s. Io. 
jednokondygnacyjny ${ }^{23}$. Grupę pasyjną tworzą Chrystus Ukrzyżowany w centrum oraz rzeźby świętych Jana i Maryi. W podstawie ołtarza znajduje się napis INRI, natomiast część centralną - retabulum - zajmuje figura Chrystusa w kolorze czarnym ze złotym perizonium na czerwonym tle (ryc. 4). Po bokach umieszczone są figury Maryi i Jana w kolorze ciemnobrązowym ze złotymi lamówkami na brązowym tle. Całość utrzymana jest w ciemnobrązowych barwach z delikatnymi złoceniami.

Pozostaje tajemnicą, dlaczego figurę Chrystusa przedstawiono w czarnej barwie i co chciał w ten sposób przekazać artysta. W kwerendach bibliotecznych i archiwach brakuje informacji na temat wilamowskiego zabytku.

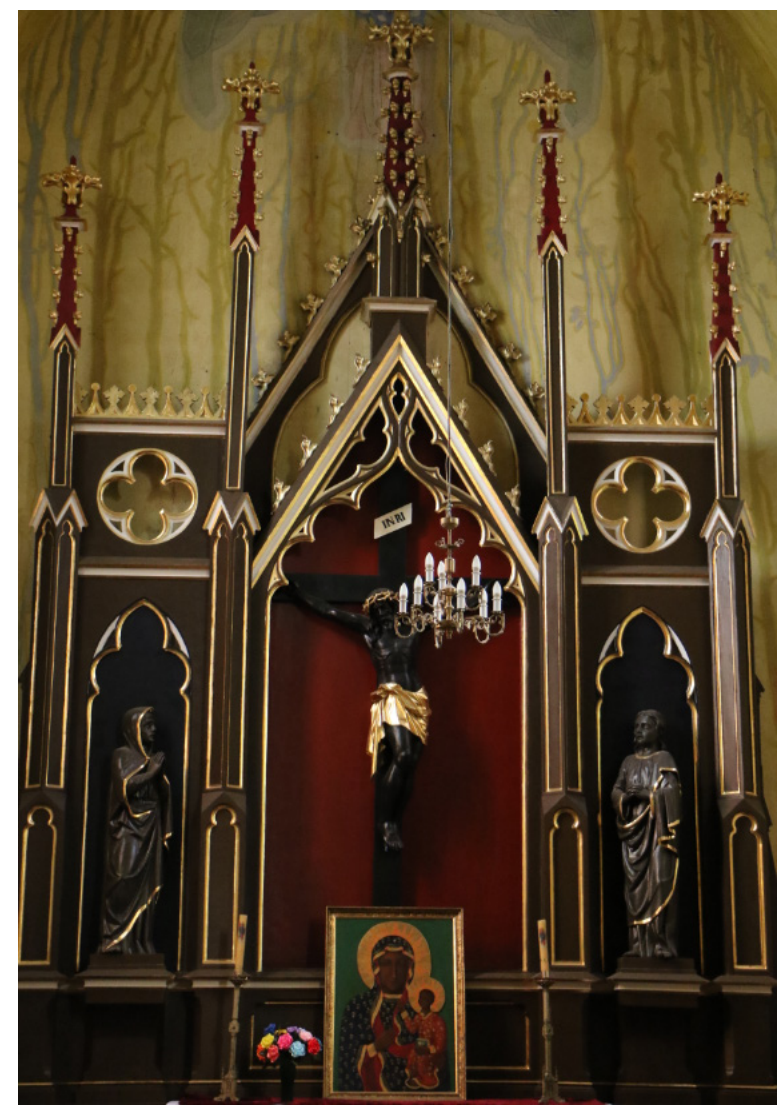

Ryc. 4. Ołtarz boczny z figurą Chrystusa Ukrzyżowanego

Źródło: galeria zdjęć Urzędu Miasta w Uniejowie

23 K. Kannenberg, Dokumentacja prac konserwatorskich i restauratorskich. Ottarz boczny Chrystusa Ukrzyżowanego, Toruń 2019, s. 5. 
Według informacji pozyskanych od proboszcza autorstwo należy przypisać artystom pochodzącym z Krakowa.

Podobny czarny krucyfiks znajduje się w krakowskiej Katedrze Wawelskiej. Jest on artystycznym wyrażeniem żałoby. Motyw krucyfiksu wawelskiego owianego licznymi legendami przez lata rozpalał wiarę wśród wiernych modlących się w katedrze, a także inspirował artystów, urastając niejako do rangi symbolu polskiej historii i tradycji nieodłącznie związanych z wiarą katolicką. W czasie zaborów, gdy Polska nie istniała na mapie Europy, a Kraków stał się duchową stolicą Polaków, tym większa była siła jego oddziaływania. Można zatem przypuszczać, że kolorystyka ołtarza wilamowskiego została utrzymana w tej samej, żałobnej konwencji, nawiązując do niebytu polskiej państwowości ${ }^{24}$.

W nawach bocznych zachowano jeszcze fragmenty ołtarzy drewnianych, neogotyckich, pochodzących z poprzedniego, drewnianego kościoła. W lewej nawie znajduje się ołtarz z centralnym obrazem św. Wojciecha. Jest to obraz olejny, malowany na płótnie. Nad nim umieszczono mniejszy obraz z wizerunkiem św. Tekli, panny i męczennicy. Po bokach ołtarzy stoją dwie drewniane figury: św. Wojciecha i św. Stanisława. W prawej bocznej nawie stoi ołtarz z obrazem Serca Jezusowego, a po bokach umieszczono rzeźby św. Piotra i św. Pawła. U góry nad ołtarzem wisi obraz św. Barbary, panny i męczennicy.

\section{Organy}

Nieodłącznym elementem wyposażenia kościoła są organy, które zarówno pod względem rozmiarów przestrzennych, różnorodności źródeł fal dźwiękowych, mocy emitowanej do otoczenia, rozmaitości kształtów i ornamentyki oraz złożoności konstrukcyjnej są nieporównywalne z żadnym innym instrumentem. W wielu aspektach, takich jak: głośność czy możliwości brzmienia pod rękoma (i nogami) dobrze wyszkolonego wirtuoza brzmią jak cała orkiestra symfoniczna, chociaż gra na nich jeden człowiek ${ }^{25}$. Tylko na tym instrumencie można poprzez dobór rejestrów uzyskać brzmienie odpowiednie do okresu liturgicznego czy poszczególnych części mszy św.; w okresie radosnym Gloria in excelsis Deo może wybrzmieć z miksturą, głośno i radośnie, a w okresie pokutnym

24 P. Worwa, Królowa Jadwiga i czarny krucyfiks, [online] Królowa Jadwiga i Czarny Krucyfiks - Chwata Zapomniana, chwalazapomniana.pl [dostęp: 27.05.2021].

25 Organy, [online] https://pl.wikipedia.org/wiki/Organy [dostęp 27.05.202I]. 
posłużą do tego delikatne kantyki na głosach fletowych. Nic dziwnego, że organy uważane są powszechnie za króla instrumentów, a kościół uznaje je za jedyny instrument godny towarzyszenia celebracji liturgicznej.

W Konstytucji Soboru Watykańskiego II „Sacrosanctum concilium” czytamy:

W Kościele łacińskim należy mieć $\mathrm{w}$ wielkim poważaniu organy piszczałkowe jako tradycyjny instrument muzyczny, którego brzmienie ceremoniom kościelnym dodaje majestatu, a umysły wiernych podnosi do Boga i spraw niebieskich" ( $\mathrm{nr}$ I20) ${ }^{26}$.

Organy, które znajdują się w Wilamowie, zostały zbudowane przez warszawskiego organomistrza Ignacego Karczewskiego w I90 r r. Metryka w postaci tabliczki znamionowej potwierdza autorstwo i warsztat, w którym powstał ten czternastogłosowy instrument o romantycznej estetyce brzmienia. O samym budowniczym wiadomo niewiele. Dotychczasowa literatura przedmiotu nie zawiera kompletnego wykazu prac Karczewskiego. Wiadomo jednak, że w I872 r. remontował XVIII-wieczne organy w Mariańskim Porzeczu ${ }^{27}$. Karczewski reprezentował stosunkowo konserwatywny nurt budownictwa organowego, stosując rozwiązania techniczne charakterystyczne jeszcze dla schyłku XIX w. W organach wilamowskich występuje system czysto mechaniczny (tzw. traktura mechaniczna), podczas gdy już od ostatnich dekad XIX w. powszechnie stosowano systemy opierające się na tzw. aparatach pneumatycznych, znacząco ułatwiających grę i zmniejszających opory pracy instrumentu ${ }^{28}$. Listę rejestrów przedstawiono w tab. I.

Wilamowskie organy piszczałkowe to prawdziwa perełka historycznego organomistrzostwa, choćby z uwagi na fakt, że nie zachowało się wiele realizacji mistrza Karczewskiego, a ponadto organy utrzymane w dobrym stanie i odpowiednio zadbane w polskich kościołach należą dziś do rzadkości. Wiele z nich uległo zniszczeniu w wyniku upływającego czasu, a te, które ocalały, są albo zaniedbane, albo niesprawne. Dość często zdarza się,

26 Konstytucja o Liturgii Świętej „Sacrosanctum Concillium”, [online] Konstytucja o liturgii świętej „Sacrosanctum concilium”, ptm.rel.pl [dostęp: 27.05.202I].

27 Goźlińskie brzemiennie, [online] „Echo Katolickie” 2019, https://www.echokatolickie. $\mathrm{pl} /$ index.php?str=IOO\&id=I5887 [dostęp: 27.05.2021].

28 Konsultacja z dr hab. prof. AMŁ K. Urbaniakiem, rzeczoznawcą w dziedzinie instrumentów muzycznych o specjalizacji organy piszczałkowe z ramienia Ministra Kultury, Dziedzictwa Narodowego i Sportu. 
że wspaniałe niegdyś instrumenty przestają funkcjonować z powodu braku należytej troski, a w konsekwencji popadają w ruinę i zapomnienie. Organy w Wilamowie zachowały swoją pierwotną formę niemal w całości z wyjątkiem frontowych piszczałek, które najprawdopodobniej zostały skonfiskowane w okresie I wojny światowej na potrzeby przemysłu zbrojeniowego z uwagi na cenny kruszec, z którego zostały wykonane ${ }^{29}$.

Tabela I. Dyspozycja instrumentu

\begin{tabular}{c|c|c}
\hline Manual & Pedał & Pomoce \\
\hline I. Pryncypał 8' & I. Bourdon 16' & M.-P \\
\hline 2. Oktawa 4' & 2. Violon 8' & Tremolo \\
\hline 3. Viola di Gamba 8' & 3. Pryncypat 8' & \\
\hline 4. Bourdon 8' & 2. Oktawa 4' & \\
\hline 5. Aeolina 8' & & \\
\hline 6. Portunal 8' & & \\
\hline 7. Dolcet 4' & & \\
\hline 8. Rorflet 4' & & \\
\hline 9. Quinta 3' & & \\
\hline Io. Mikstura 3-chór. 2' & & \\
\hline
\end{tabular}

Źródło: Kościótśw. Wojciecha iśw. Stanistawa, [w:] Musicam Sacram, [online] https:// musicamsacram.pl/instrumenty/opis/2163-Wilamow-Kosciol-sw-Wojciecha-i-sw-Stanislawa [dostęp 27.05.202I]

29 W 1917 r. ogłoszono powszechną mobilizację do oddania piszczałek pochodzących z organów kościelnych, które zazwyczaj wykonywano z metali kolorowych. Urzędowym postanowieniem odpowiednio delegowane firmy przemierzały kolejne parafie, demontując oryginalne piszczałki, które z czasem uzupełniano, jednak już nie pierwotnym surowcem, a mniej cenną blachą cynkową. Na łamach „Gazety Zgierskiej” z dnia I2 maja I9I7 r. pojawiło się obwieszczenie dotyczące „sekwestru i wywłaszczania wszystkich dachów miedzianych, pokrywających katolickie i ewangelickie kościoły, synagogi i żydowskie domy modlitwy oraz piszczałek cynowych przy wszystkich organach, znajdujących się w obrębie Jenerał-Gubernatorstwa Warszawskiego". W rozporządzeniu sugerowano wprost, że wyjęte piszczałki najlepiej zastąpić analogicznymi piszczałkami drewnianymi na wzór przerobionych organów Filharmonii Warszawskiej lub w przypadku ich braku zasłonić puste miejsce drewnianymi listwami, co uczyniono w odniesieniu do organów w katedrze na placu Saskim. Metale należało samodzielnie dostarczać do urzędów powiatowych albo do składów skupu metali Wydziału Surowców Wojennych lub też były one przymusowo wywłaszczane przez komendy 
Instrument przez długi czas nie był remontowany ani strojony, podczas włączania połączenia odzywały się niektóre dźwięki losowych głosów ${ }^{30}$. Dopiero w 2006 r. na kilka tygodni przed odejściem na emeryturę ówczesnego proboszcza, ks. Jana Sroki, przeprowadzono kompletny remont organów ${ }^{31}$, dzięki któremu po dziś dzień są sprawne i mogą być ozdobą celebracji liturgicznej oraz nadawać majestat w czasie różnych kościelnych ceremonii.

\section{Gotycka chrzcielnica/kropielnica}

We wnętrzu kościoła zwraca uwagę umieszczona w przedsionku kropielnica z charakterystyczną ornamentyką, nawiązującą ikonograficznie do chrzcielnic typu skandynawskiego. Płaskorzeźby pokrywające ośmioboczną czaszę przywołują skojarzenia odnoszące się bardziej do sztuki romańskiej niż do epoki romantyzmu, z którego pochodzi kościół. Chrzcielnica wzbudza zainteresowanie, ponieważ zupełnie nie przystaje do spójnego, utrzymanego w stylu neogotyckim wyposażenia kościoła.

Oględziny kropielnicy pozwalają dostrzec wizerunki fantastycznych zwierząt i ptaków, smoków, dwugłowego orła, a także diabła stanowiących przestrogę, w myśl której szatan usiłuje udaremnić ludzkie zbawienie. Pod krawędzią czaszy artysta wyrzeźbił fryz ze stylizowanych palmetek, przypominających nieco heraldyczne lilie.

Wilamowska chrzcielnica (obecnie wykorzystywana jako kropielnica) przypomina kształtem kielich, składa się z trzech części (stopa i trzon stanową podstawę, część górna to ośmioboczna misa) i wykonana jest z twardego wapienia (ryc. 5). Ten typ chrzcielnic rozpowszechnił się w XII w. w północnych krajach Europy, zwłaszcza w Danii i Szwecji ${ }^{2}$. Pod względem kształtu nawiązuje bezpośrednio do symboliki kielicha eucharystycznego, określanego jako typ Grobu Pańskiego, w którym

robotnicze Wydziału Surowców w Łodzi. Naruszenie postanowienia podlegało karze pozbawienia wolności do pięciu lat, wysokiej karze finansowej lub obu karom jednocześnie; zob. „Gazeta Zgierska”, nr 38, Zgierz I2 maja I9I7 r., s. I-2.

30 Kościót św. Wojciecha i św. Stanisława, [online] Musicam Sacram, https://musicamsacram.pl/instrumenty/opis/2163-Wilamow-Kosciol-sw-Wojciecha-i-sw-Stanislawa [dostęp: 27.05.202I].

3I M. Bartosiak, Ksiądz Jan Sroka odszedt na emeryture, „W Uniejowie” 2006, nr 27, s. Io. 32 J. Kuczyńska, Średniowieczne chrzcielnice kamienne w Polsce, „Rocznik Historii Sztuki” I984, t. XIV, z. 4 - Historia Sztuki, s. 8. 
składane jest mistyczne ciało Jezusa ${ }^{33}$. Poprzez kształt zbliża się do tajemnic Eucharystii, identyfikując się z kielichem z Ostatniej Wieczerzy, i niesie zapowiedź zbawienia oraz nadzieję odrodzenia ze Zmartwychwstałym. Formę kielichową chrzcielnicy można wreszcie uznać za najpełniejszy wyraz głównych treści symboliki chrztu, wedle których sakrament wybawia skutecznie człowieka od złych mocy ${ }^{34}$.

Karta ewidencyjna wilamowskiego zabytku udostępniona przez Wojewódzki Urząd Ochrony Zabytków ${ }^{35}$ wskazuje na Gotlandię jako miejsce pochodzenia, choć przy informacji o proweniencji postawiono znak zapytania. Ponadto zabytek określony jest jako gotycki z uwagi na oktagonalny kształt czaszy i podstawy oraz kielichową formę. Z kolei Jadwiga Kuczyńska uważa, że chrzcielnice zdobione motywem fantastycznych zwierząt należą pod względem formalnym raczej do stylu późnoromańskiego. O ile karta

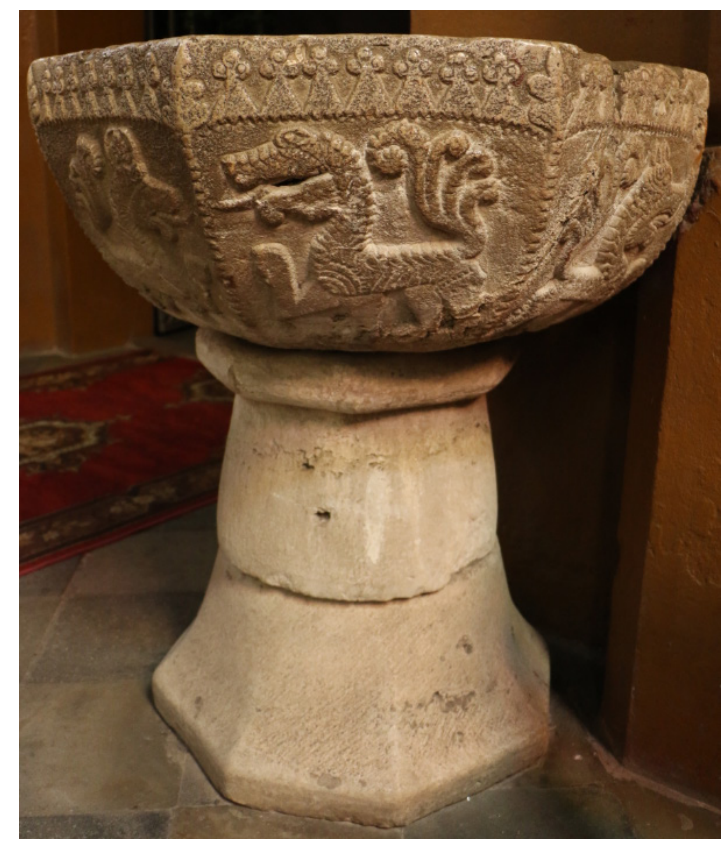

Ryc. 5. Chrzcielnica

Źródło: galeria zdjęć Urzędu Miasta w Uniejowie

33 J. Nowiński, Teologia Eucharystii w sztuce sakralnej-wybrane przykłady z kategorii vasa sacra, [w:] A.S. Czyż, K. Moisan-Jabłońska (red.), Pióro na wodzie, Warszawa 2015, s. I22.

34 J. Kuczyńska, Średniowieczne chrzcielnice..., s. I3.

35 F. Tomaszewski, Tajemnica wilamowskiej chrzcielnicy, „Uniejowskie Strony” 2010, nr 5 (25), s. 35 . 
ewidencyjna zabytku datuje chrzcielnicę wilamowską na okres I370-I430, o tyle prof. Kuczyńska podaje raczej trzecią ćwierć XIV w., ale nie wyklucza też około poł. XIV w., wskazując na pokrewieństwo formalne z chrzcielnicami gotlandzkimi grupy Fjörel, datowanymi na ten okres. Przykładem są chrzcielnice w Uggerslev (Dania), Ölst (Holandia), Træden (Dania) oraz Magleby (Dania) ${ }^{36}$.

Jedną z kluczowych i jak dotąd nierozstrzygniętych jednoznacznie kwestii jest odnalezienie powiązań Wilamowa z Gotlandią, co mogłyby dać odpowiedź na pytanie, w jaki sposób skandynawski zabytek znalazł się w tymże kościele.

Gotlandia, zwana także Wyspą Wikingów, jest największą wyspą na Morzu Bałtyckim, znajdującą się około $90 \mathrm{~km}$ na południe od Półwyspu Skandynawskiego. Od zawsze wyspa była miejscem tranzytowym pomiędzy ludami północy i południa. Jak zauważa F. Tomaszewski, w XII w. wyspa przeżywała okres wyjątkowego, artystycznego rozkwitu pod egidą stylu romańskiego. Dostępność odpowiedniego materiału (piaskowca) oraz szczególne położenie wyspy na skrzyżowaniu szlaków morskich pomiędzy schrystianizowaną wówczas Skandynawią i pogańskimi plemionami nadbałtyckimi a piastowską Polską i prawosławnym Nowogrodem pozwoliło wytworzyć niepowtarzalny nurt w sztuce i rzeźbie, łączący w sobie wzorce zarówno zachodnioeuropejskie, bizantyńskie, jak i pogańskie, co w efekcie przełożyło się na niepowtarzalny koloryt artystyczny na przełomie XII i XIII w. ${ }^{37}$

Gotlandia stanowiła ważny ośrodek wymiany towarowej. Ludność zamieszkująca wyspę uprawiała daleko sięgający handel zamorski. Największe miasto Gotlandii, obecnie stolica - Visby, stanowiło kolebkę Związku Hanzeatyckiego i wybiło się na jego czoło, prowadząc dobrze rozwiniętą politykę handlu zagranicznego. Kamieniarze wyspecjalizowani w ekskluzywnej płaskorzeźbie romańskiej eksportowali gotowe wyroby, które zdobiły wznoszone wówczas kamienne katedry i klasztory na całym niemal basenie Morza Bałtyckiego, w tym również chrzcielnice, jak i sam surowiec. Kamień gotlandzki był wysoko ceniony przez kamieniarzy i rzeźbiarzy za łatwość obróbki ze względu na jego miękkość i drobnoziarnistość przy jednocześnie dużej spoistości. Z tego powodu importowano go w znacznych ilościach ${ }^{38}$.

36 J. Kuczyńska, Średniowieczne chrzcielnice..., s. 27.

37 G.B. Bednarek, Gotlandzka chrzcielnica z Wilamowa, XIII-XIV w., [online] „Katolickie Media” 20I7, katolickie.media.pl [dostęp: 27.05.202I].

38 F. Tomaszewski, Tajemnica wilamowskiej chrzcielnicy, „Uniejowskie Strony” 2010, nr 5 (25), s. 3 . 
Chrzcielnice wysyłano do Szwecji, Danii, Szlezwika-Holsztynu, Meklemburgii, Prus i Pomorza Zachodniego. Importowi sprzyjały istniejące ówcześnie powiązania Pomorza Zachodniego ze Skandynawią, w tym z Gotlandią, do czego przyczynił się m.in. fakt uznania przez księcia pomorskiego Bogusława w II85 r. zwierzchnictwa lennego króla duńskiego Knuta, co trwało do I23I r.

Prof. J. Kuczyńska zwraca uwagę na chrzcielnice wytwarzane w warsztatach gotlandzkich od około poł. XIII w. do końca XIV w., a przeznaczone głównie na eksport:

Chrzcielnice te, doskonałe technicznie, posiadają harmonijne proporcje kielicha trzyczęściowego. W dekoracji chrzcielnic wytwarzanych około połowy XIII wieku dominował motyw arkady, natomiast tematem dekoracji chrzcielnic wykonywanych $\mathrm{w}$ drugiej połowie XIV w. były przedstawienia fantastycznych zwierząt i masek ${ }^{39}$.

Powyższy opis idealnie pasuje do zabytku z Wilamowa. Na terenie Polski zachowało się łącznie około 400 kamiennych chrzcielnic średniowiecznych ${ }^{40}$, które reprezentują zróżnicowany materiał zabytkowy pod względem artystycznym. Na ich tle można wyodrębnić kilka ocalałych z dziejowej zawieruchy, które pod względem dekoracji są spójne z zabytkiem wilamowskim: to dwie czasze znajdujące się w Elblągu (w kościele św. Jakuba) i w Grudziądzu (w kościele św. Mikołaja) oraz czasza z nieistniejącego kościoła w miejscowości Lubiana (gm. Pełczyce, woj. zachodniopomorskie), przechowywana obecnie w Muzeum Narodowym w Szczecinie. Zaledwie dwie chrzcielnice zachowały się w całości - jedna z nich znajduje się w Chełmnie (w woj. kujawsko-pomorskim), a druga w Wilamowie.

Jeśli wobec powyższego chrzcielnica z Wilamowa jest rzeczywiście gotlandzkim importem, wciąż nie wiadomo, w jaki sposób trafiła do świątyni. Zważywszy na fakt, że pierwsza wzmianka o wsi pochodzi z I232 r., a parafia została erygowana w XV w., można przypuszczać, że chrzcielnica została pozyskana do parafii raczej z „rynku wtórnego”.

Niektóre źródła podają także, że odkuł ją wędrowny kamieniarz zainspirowany skandynawską ornamentyką, o czym miałoby świadczyć tworzywo - bardzo twardy kamień, niespotykany w Gotlandiii ${ }^{11}$. Niezależnie

39 J. Kuczyńska, dz. cyt., s. Io.

40 Odpowiedni surowiec określony był już w 524 r. na soborze w Lleida w Katalonii, gdy nakazano używać kamienia do wyrobu zbiorników chrzcielnych.

4I J. Kuczyńska, dz. cyt., s. 27. 
jednak od tego, gdzie i czyją ręką została wykonana, stan zachowania, forma, wielkość i kunszt rzeźb czynią zeń jeden z najbardziej wartościowych obiektów tego typu w kraju.

Biorąc pod uwagę jej usadowienie w maleńkim kościele, łatwo pokusić się o hipotezę, że była przeznaczona do zacniejszego obiektu sakralnego, jak choćby archikolegiata łęczycka czy sama katedra włocławska, jednak w zawierusze dziejów z jakichś względów tam nie dotarła.

\section{Polichromia}

Ściany świątyni zostały pokryte polichromią wykonaną przez krakowskich malarzy Barbarę i Rudolfa Świechów. Malatura datowana jest na 1955 r., o czym informuje protokół powizytacyjny z lat $1948-1996^{42}$, z formalnego punktu widzenia nie stanowi więc warstwy zabytkowej, niemniej kunszt artystyczny oraz bogata plastyka wnętrza zasługują na choćby krótki komentarz.

Polichromia sklepienia podporządkowana jest podziałom architektonicznym o dominującym kolorze niebieskim i zielonym w prezbiterium i nawie głównej z łagodnym przejściem do barw ciepłych na malowidłach pokrywających ściany naw i kaplice, nie zakłócając estetycznie wnętrza, ale eksponując jego walory.

Pod względem wzornictwa oprócz przedstawień figuralnych artyści posłużyli się ornamentyką o motywach geometrycznych i stylizowanych roślinnych. Forma, którą nadali realizacji, uwarunkowana jest architekturą świątyni. Dostosowanie polichromii do wnętrza podyktowane było przyjętą zasadą czytelności i jasności wprowadzanych rozwiązań. Mając świadomość tworzenia w miejscu użyteczności publicznej, artyści zadbali o jasny przekaz prezentowanych treści. Temu celowi służyć miało m.in. opatrzenie poszczególnych wizerunków świętych inskrypcjami. Reguła czytelności widoczna jest także w doborze scen figuralnych. Dla prezbiterium państwo Świech zaprojektowali sceny z życia świętych patronów kościoła, decydując się na odzwierciedlenie jak najbardziej reprezentatywnych ujęć.

Dostosowanie malatury do wnętrza widoczne jest także w kaplicach bocznych - koresponduje z ołtarzami, tworząc jedną, spójną tematycznie całość. W przypadku ołtarza z podobizną Madonny z Dzieciątkiem ścianę pokrywają malowidła z wizerunkiem Matki Boskiej i z elementami roślinnymi, które

42 Archiwum Parafialne, Sprawozdanie wizytacyjne, I948-1996. 
budzą skojarzenia związane z różańcem. Z kolei po przeciwnej stronie tłem dla ołtarza pasyjnego są ciernie, całości dopełnia unoszący się nad ołtarzem anioł z rozłożonymi skrzydłami, co wyraża ideę planu ludzkiego zbawienia wypełnionego w męce Jezusa Chrystusa. W tym wypadku polichromia harmonizuje z wystrojem i podkreśla jego rangę historyczną.

Polichromia pokrywa niemal całe wnętrze kościoła. Bogata treść religijna dostosowana jest do wystroju wnętrza. Same prace malarskie były doniosłym wydarzeniem w życiu mieszkańców, którzy wspierali artystów, dostarczając niezbędne produkty do wykonania ręcznie przygotowywanych farb ${ }^{43}$.

\section{Wartość historyczno-artystyczna obiektu i jego potencjał w kontekście turystyki kulturowej}

Kościół w Wilamowie, będący zabytkiem architektury ujętym w wojewódzkiej i gminnej ewidencji zabytków, reprezentuje określony etap w historii i odgrywa istotną rolę w życiu religijnym, ale też społecznym. Jest to dzieło neogotyckiej, romantycznej sztuki sakralnej, o bezspornej wartości historycznej. Jeśli przyjąć, że jej nośnik stanowi oryginalna substancja zabytkowa, w omawianym obiekcie istotnie jej nie brakuje. Jest ona dobrze widoczna i czytelna, zarówno na zewnątrz, jak i we wnętrzu świątyni. Wprawdzie recepcję tej cechy może zakłócać dostosowane do współczesnych standardów otoczenie, pewien dysonans mogą także powodować ławki, które nie mają uzasadnienia historycznego, mimo to nie zaburzają one ogólnie pozytywnego odbioru estetycznego. Co więcej, zagospodarowanie terenu z przylegającym bezpośrednio do posesji malowniczym ogrodem niewątpliwie stanowi atut i dodaje miejscu romantycznego charakteru ${ }^{44}$.

Zgodnie z powyższym obiekt wykazuje duży potencjał turystyczny i może stanowić propozycję eksploatacji turystycznej na zdecydowanie większą skalę niż dotychczas, zarówno dla pojedynczego turysty, jak i dla grup. Atutem jest także bliskie usytuowanie głównych tras komunikacyjnych, co

43 Informacja pozyskana od proboszcza.

44 Jednym z działań podjętych przez obecnego administratora parafii była budowa Groty Matki Bożej z Lourdes w 2010 r. Modlitewną kaplicę wzniesiono wśród zieleni, na przedpolu kościoła, poświęcił ją ordynariusz Diecezji Włocławskiej, bp Wiesław Mering. Na terenie przykościelnym upamiętniono ofiary zbrodni katyńskiej, sadząc w 2008 r. Dąb Pamięci, poświęcony Antoniemu Paczesnemu, mieszkańcowi Wilamowa, zastrzelonemu przez żołnierzy radzieckich. W 2012 r. odsłonięto także obelisk z pamiątkową tablicą. 
wpływa na łatwą dostępność obiektu, oraz dość duża liczba miejsc parkingowych w bezpośrednim sąsiedztwie kościoła. Jedną z ciekawych opcji byłoby włączenie obiektu do szlaku kulturowego, nawiązującego do określonego tematu. Mogłyby się znaleźć w nim takie obiekty sakralne, jak kolegiata w Uniejowie czy położone kilkanaście kilometrów od Wilamowa Świnice Warckie z Sanktuarium Urodzin i Chrztu św. Faustyny.

Pisząc o potencjale turystycznym, nie sposób pominąć słabych stron, które powodują, że ciekawy kulturowo obiekt jest niedoceniany i w konsekwencji mało znany. W pierwszej kolejności należy wymienić słabą popularyzację. Udokumentowane walory historyczne i artystyczne umiejętnie przedstawione zapewne stałyby się zachętą do odwiedzenia świątyni przez osoby zainteresowane sztuką sakralną.

Problemem jest także niedostateczne oznaczenie znaków przydrożnych (tzw. brązowych znaków) informujących o zabytku. Przy samym kościele tablica informacyjna niewystarczająco podkreśla walory świątyni, co powoduje, że turyści nawet gdy trafią do Wilamowa, dowiadują się o niej niewiele. Przeprowadzone obserwacje terenowe potwierdzają to spostrzeżenie. Brakuje także fachowo sporządzonych i dostępnych w odpowiednich miejscach folderów czy broszurek, które informowałyby o zabytku. Tę lukę miała wypełnić ulotka wydana z okazji stulecia konsekracji kościoła w 2009 r., ale niestety jej nakład szybko okazał się niewystarczający, a nie był wznawiany. Kolejny problem stanowi dostępność wnętrza. Kościół jest dostępny przez cały rok, ale poza mszami i uroczystościami pozostaje w zasadzie zamknięty. Nie zastosowano także rozwiązania tzw. zamkniętej kraty, która umożliwiałaby wgląd do jego wnętrza. Naprzeciw sytuacji wychodzi przychylny proboszcz, który poproszony o otwarcie kościoła, nie pozostaje obojętny na prośby.

Wreszcie bliskie położenie Uniejowa może paradoksalnie wpłynąć na mniejszą eksplorację różnorodnych obiektów znajdujących się w pobliżu miasta, które w naturalny sposób absorbuje uwagę odwiedzających. Tę sytuację można jednak zmienić za sprawą odpowiednich działań promocyjnych i informacyjnych, dzięki którym nastąpiłoby wzbogacenie oferty regionu w kontekście turystycznym.

\section{Podsumowanie}

Neogotycki kościół w Wilamowie posiada niewątpliwie walory artystyczne stanowiące o jego atrakcyjności, które mogą uczynić zeń miejsce wypraw kulturowych. Wartość zabytku nie znalazła jednak należytego oddźwięku 
w opracowaniach krajoznawczych, co może wpłynąć na jego niewielką znajomość wśród potencjalnych zwiedzających. Tymczasem estetyka, dogodne położenie i autentyczność wykazują duży potencjał turystyczny, zwłaszcza w odniesieniu do turystyki dziedzictwa kulturowego. Aktualnie realizowana strategia rozwoju gminy zakłada przeprowadzenie niezbędnych prac remontowych w obiektach zabytkowych oraz dbałość o ich kondycję techniczną w celu ochrony dziedzictwa kulturowego ${ }^{45}$. W latach 2019-2020 z inicjatywy burmistrza gminy Józefa Kaczmarka i w porozumieniu z władzami diecezjalnymi oraz parafialnymi w Uniejowie, Wilamowie oraz w Spycimierzu zrealizowano wspólny projekt pod nazwą „Kształtowanie przestrzeni publicznej w Gminie Uniejów”. Pozyskano na ten cel środki unijne i wykorzystano je na nowe zagospodarowanie otoczenia kościołów i terenów związanych z kultem religijnym w każdej z wyżej wymienionych parafii. Oprócz przekształceń infrastrukturalnych potrzebne jest jednak prowadzenie działań informacyjno-promocyjnych, które zwiększyłyby zainteresowanie turystów zabytkami w gminie Uniejów, w tym występującymi tu obiektami sakralnymi. Opisany w artykule wilamowski kościół na pewno zasługuje na to, aby znaleźć się na turystycznym szlaku tematycznym, gdyż stanowi istotny element dziedzictwa kulturowego gminy.

\section{Bibliografia}

\section{Źródła piśmiennicze}

Akta parafialne dotyczące ołtarza, 1964, pismo I4047.

Archiwum Parafialne.

Archiwum Parafialne, Sprawozdanie wizytacyjne, 1948-1996.

Gmina Uniejów, Gminna Ewidencja Zabytków Gminy Uniejów.

\section{Źródła drukowane}

"Gazeta Zgierska” 19I7, I2 maja, nr 38, s. I-2.

Grabarczyk T., Kowalska-Pietrzak A., Szymczak J., Uniejowskie strony. Karty z przeszłości odległej, nieznanej i bliskiej gminy Uniejów, J. Szymczak (red.), Łódź-Uniejów 2008, s. 157.

45 Aktualizacja strategii rozwoju gminy Uniejów na lata 2013-2020, s. II8. 
Librowski S., Repetytorium Akt Wizytacji Kanonicznych dawnej archidiecezji gnieźnieńskiej, t. I, z. I, s. 97.

Łaski J., Liber Beneficiorum Archidioecesis Gnesnensis, t. I, Gniezno I880, s. 363 .

Kannenberg K., Dokumentacja prac konserwatorskich $i$ restauratorskich. Ottarz boczny Chrystusa Ukrzyżowanego, Toruń 2019, s. 5.

Kondracki J., Środowisko geograficzne jako podłoże rozwoju osadnictwa i gospodarki, [w:] J. Szymczak (red.), Uniejów, dzieje miasta, ŁódźUniejów I995, s. 373.

Kruk E., Terzyjska B., Dokumentacja budowy technicznej oraz prac konserwatorskich ottarza bocznego z kościoła pw. św. Wojciecha i św. Stanisława B.M. w Wilamowie, Łódź 2014, s. 8.

Kuczyńska J., Średniowieczne chrzcielnice kamienne w Polsce, „Rocznik Historii Sztuki” I984, t. XIV, z. 4 - Historia Sztuki, s. 5-79.

Nowiński J., Teologia Eucharystii w sztuce sakralnej - wybrane przykłady z kategorii vasa sacra, [w:] A.S. Czyż, K. Moisan-Jabłońska (red.), Pióro na wodzie, Warszawa 2015, s. I22.

Olszewski A., Karta wojewódzkiej ewidencji zabytków obiektu - Kościót Parafialny pw. Wojciecha i Stanistawa, 1982.

Tomaszewski F., Tajemnica wilamowskiej chrzcielnicy, „Uniejowskie Strony” 20IO, nr 5 (25), s. 35-36.

Warszycka B., Dokumentacja konserwatorska obrazu ottarzowego M.B. z Dzieciątkiem, Wilamów I995, s.I

Żmudzki P., Studium podzielonego królestwa. Ksiązę Leszek Czarny, Warszawa 2000, s. 67.

\section{Źródła internetowe}

Bartosiak M., W setną pamiątkę urodzin Ojca Świętego, Jana Pawła II..., [online] https://uniejow.pl/aktualnosci/_trashed-5.html [dostęp: 26.05.202I].

Bednarek G.B., Gotlandzka chrzcielnica z Wilamowa, XIII-XIVw., [online] „Katolickie Media” 2017, http://katolickie.media.pl [dostęp: 27.05.202I].

Bednarek G.B., Wilamów. Parafia pw. patronów Polski św. Wojciecha $i$ św. Stanistawa. Historia parafii, [online] „Katolickie Media” 20I7, http://katolickie.media.pl [dostęp: 21.05.202I].

Goźlińskie brzemiennie, [online] „Echo Katolickie” 2019, https://www. echokatolickie.pl/index.php?str=100\&id=15887 [dostęp: 27.05.202I]. 
Konstytucja o Liturgii Świętej „Sacrosanctum Concillium”, [online] Konstytucja o liturgii świętej „Sacrosanctum concilium”, ptm.rel.pl [dostęp: 27.05.2021]. Kościót św. Wojciecha i św. Stanistawa, [online] Musicam Sacram, https:// musicamsacram.pl/instrumenty/opis/2163-Wilamow-Kosciol-swWojciecha-i-sw-Stanislawa [dostęp: 27.05.202I].

Organy, [online] https://pl.wikipedia.org/wiki/Organy [dostęp 27.05.202I]. Romantyzm - charakterystyka epoki (ramy czasowe, nazwa epoki, filozofia), [online] https://eszkola.pl/jezyk-polski/romantyzm--978.html [dostęp: 26.05.202I].

Worwa P., Królowa Jadwiga i czarny krucyfiks, [online] Królowa Jadwiga i Czarny Krucyfiks - Chwata Zapomniana, chwalazapomniana.pl [dostęp: 27.05.202I].

\section{Konsultacje i wywiady}

Konsultacja z dr hab. prof. AMŁ K. Urbaniakiem, rzeczoznawcą w dziedzinie instrumentów muzycznych o specjalizacji organy piszczałkowe z ramienia Ministra Kultury, Dziedzictwa Narodowego i Sportu.

Konsultacja z proboszczem B. Karasińskim.

\section{Historical and artistic value of St Wojciech and Stanisław church in Wilamów}

SUMMARY | The neo-gothic church dedicated to St Wojciech the Bishop and Martyr and St Stanisław the Bishop and Martyr in Wilamów is an example of monumental sacral art in Uniejów municipality. In spite of its historical value and location in the vicinity of major transport routes, it is rather little known - it is commonly perceived as a village church rather than a sacral monument worth visiting. The article presents the history of the church and the parish on the basis of specialist literature as well as written and oral sources. It also describes the surroundings and the interior decorations of the church, with a particular focus on its historical and artistic value. The presented analysis demonstrates the touristic potential of this place as an element of cultural heritage.

KEYWOR D S Wilamów, church, art, artistic value

| Informacje o artykule: przyjęto - 28 maja 202I; zaakceptowano 2 lipca 2O2I 